\title{
INO80 Complex Subunit D
}

National Cancer Institute

\section{Source}

National Cancer Institute. INO80 Complex Subunit D. NCI Thesaurus. Code C125260.

INO80 complex subunit D ( $878 \mathrm{aa}, \sim 98 \mathrm{kDa})$ is encoded by the human INO80D gene. This protein plays a role in chromatin remodeling. 